\title{
REVIEWS
}

Anja Klöck (ed.)

\section{The Politics of Being on Stage}

Hildesheim, Zurich, New York: Georg Olms Verlag, 2012, 293 pages

The final chapter of this book can be read as a coda to a lively set of essays on politics and performance. It consists of a transcript of a discussion, which took place at the end of a 2010 symposium held in Leipzig, entitled The Politics of Being on Stage, an event that precipitated the production of this volume. The discussion features Juliano Mer Khamis, founder/director of the Freedom Theatre in Palestine, whose assassination at the steps of this theatre in 2011 lends the publishing of this book a sense both of poignancy and of urgency. The content of this discussion also inflects the preceding essays in important ways. Asked to reflect upon his practice, Mer Khamis talks about "being in the middle of things" in a "very specific situation" in which the choice is not whether or not to make overtly "political" theatre, for the very act of making theatre is itself "a political act". What is also striking here is that this contraction of context and artistic practice that Mer Khamis testifies to leads to a further problem in theorising that politics. "There is," he insists, "no time for reflection ... you don't have the time and the privilege." There are situations then, when "doing" political theatre becomes both inevitable and perhaps in a certain sense, impossible.

These issues are well anticipated in Anja Klöck's introduction to the volume, which deftly moves through some key debates in relation to discourses around the well-mined field of performance and politics. Klöck notes, as others have, that while the proliferation of the term "politics" in theatre and performance studies has rendered it something of a "buzzword", this very proliferation itself raises questions about how the "political" operates and becomes modulated as a concept within both scholarship and praxis. Rejecting the prosaic position of "all theatre being in some sense political," Klöck is also keen to sidestep the danger of positing a hierarchy, which associates "political performance" with a specific set of aesthetic strategies. Rather, the volume seeks to explore the potential of a range of performance practices to "transform or rupture normalising practices in performance". In doing so, this book does not set out to advance a new theory of political performance or to offer new definitions of the political in performance, but rather more modestly hopes that it "may help to actualise thinking and doing theatre in terms of different and new modes of resistance". The effect of this approach is to remind readers that the concept of the political is itself problematic, and that uses of terms and concepts of the political in theatre and performance studies need to be carefully considered and specified.

What follows are essays on a diverse range of topics, such as contemporary film acting (Kienast), arts education within the academic field (Aston), actor training and postdramatic theatre (Ernst), feminist theatre practice (Rosenberg and Johansson), and the theatre of Augusto Boal (Bala). These essays deal with the concept of the political in various ways, sometimes directly or indirectly with respect to the way in which the political is theorised. Joe Kienast's essay is an example of the latter; it deals not so directly with a concept of the political as such, but with how acting styles are partly determined by a broader economic and political context. Here, Kienast makes a nuanced distinction between the more traditional Method 
Acting approach to character creation in mainstream Hollywood film, and the acting persona of contemporary film star Leonardo Di Caprio. Di Caprio, Kienast argues, moves between "the requirements of Method Acting's truthfulness and ambition" and the "brand identity" within the context of the demands of the contemporary film industry, which secures his "bankability". Sruti Bala, on the other hand, takes on a more directly politicised topic in dealing with Augusto Boal and the notion of the "spec-actor". Bala takes on the notion of spectatorship within Boal, noting that, while Boal's (mainly derisive) statements about the theatre spectator appear to lack a certain nuance, reflections on the way in which spectatorship operates within the structure of The Theatre of the Oppressed reveals a far more complex picture. Moreover, Bala argues, the "subject position" of the spectator is "woven into the fabric" of Forum Theatre as a practice. Elaine Aston takes on wider issues, which relate to the politics of the institution, and in particular an increasingly prevalent disciplinary context, which works from a "homogenised view of the arts as all being the same". Here, Aston suggests that calls for "cross-arts collaboration or integrated departmental organisation” might best be seen as veiled attempts to undermine or cut arts disciplines. In conjunction with this view, Aston also picks up on Shannon Jackson's analysis of the "deconstructive turn of thinking" in performance theory since the 1980s, and argues that this has been to the detriment of practice and the theorisation of practice. "The urgent question," Aston argues, "is how to re-conjugate theory and practice."

This, then, offers a flavour of the essays presented in this volume. The chapters are organised into three sections: "Acting and Being: Politics Theories and Practices", "Politics of Training: Traditions, Institutions and Promises", and "Activist Acting: Spectatorship, Scholarship and Responsibility". Within these broad areas, each chapter considers in some way the relationship between politics, being and stage. Although, as noted above, this text makes no pretentions towards re-examining the concept of the political in performance per se, it will still leave readers with a number of important questions. Amongst these questions, one of the most important concerns, where to locate the political in relation to performance work with respect to factors such as the agency of the artist, the situation of the performance before a specific audience, and the broader context of spectatorial reception. With contributions on a range of topics made here by scholars and practitioners, this book should be of interest to a wide range of readers concerned with the politics of performance.

\section{Cormac Power, Northumbria University}

